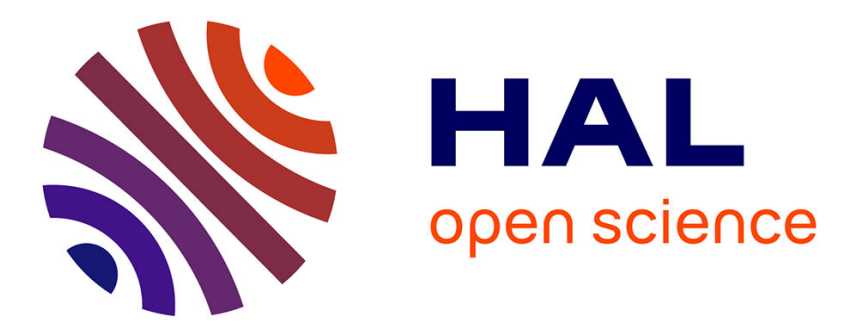

\title{
The Decolonial Eye/I: Decolonial Enunciations of Queer Diasporic Practices
}

\author{
Sandeep Bakshi
}

\section{To cite this version:}

Sandeep Bakshi. The Decolonial Eye/I: Decolonial Enunciations of Queer Diasporic Practices. Interventions: International Journal of Postcolonial Studies, 2020, Decolonial Trajectories, 22 (4), pp.533551. 10.1080/1369801X.2020.1749707 . hal-03362237

\section{HAL Id: hal-03362237 https://hal.science/hal-03362237}

Submitted on 3 Oct 2021

HAL is a multi-disciplinary open access archive for the deposit and dissemination of scientific research documents, whether they are published or not. The documents may come from teaching and research institutions in France or abroad, or from public or private research centers.
L'archive ouverte pluridisciplinaire HAL, est destinée au dépôt et à la diffusion de documents scientifiques de niveau recherche, publiés ou non, émanant des établissements d'enseignement et de recherche français ou étrangers, des laboratoires publics ou privés. 


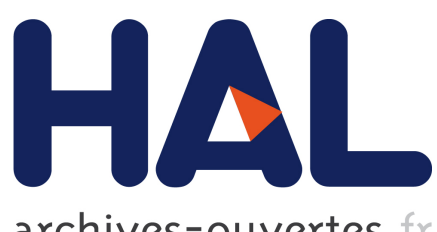

archives-ouvertes

\title{
The Decolonial Eye/I: Decolonial Enunciations of Queer Diasporic Practices
}

\author{
Sandeep Bakshi
}

\section{To cite this version:}

Sandeep Bakshi. The Decolonial Eye/I: Decolonial Enunciations of Queer Diasporic Practices. Interventions: International Journal of Postcolonial Studies, Taylor \& Francis (Routledge), 2020, 22 (4), pp.533-551. 10.1080/1369801X.2020.1749707 . hal-03362237

\section{HAL Id: hal-03362237 \\ https://hal.archives-ouvertes.fr/hal-03362237}

Submitted on 3 Oct 2021

HAL is a multi-disciplinary open access archive for the deposit and dissemination of scientific research documents, whether they are published or not. The documents may come from teaching and research institutions in France or abroad, or from public or private research centers.
L'archive ouverte pluridisciplinaire HAL, est destinée au dépôt et à la diffusion de documents scientifiques de niveau recherche, publiés ou non, émanant des établissements d'enseignement et de recherche français ou étrangers, des laboratoires publics ou privés. 


\section{The Decolonial Eye/l: Decolonial Enunciations of Queer Diasporic Practices}

\section{Sandeep Bakshi}

To cite this article: Sandeep Bakshi (2020) The Decolonial Eye/l: Decolonial Enunciations of Queer Diasporic Practices, Interventions, 22:4, 533-551, DOI: 10.1080/1369801X.2020.1749707

To link to this article: https://doi.org/10.1080/1369801X.2020.1749707 


\title{
THE D ECOLONIAL EYE/I: D ECOLONIAL ENUNCIATIONS OF QUEER DIASPORIC PRACTICES
}

\section{Sandeep Bakshi}

Department of English/Études Anglophones, Université de Paris, LARCA, CNRS, F-75013 Paris, France

\begin{abstract}
-............. Drawing upon decolonial enunciation and cultural practices, this essay
Decolonial gestures towards the development of a decolonial sensing of queer diasporic aesthesis artmaking. The key focus of the essay is the crossing of queer and decolonial thinking. A sustained critical reflection on these two theoretical decolonial queer sites is crucial, in my view, to offer a fuller comprehension of acts, practices diasporas and, broadly, cultures. Decolonial thinkers such as Walter Mignolo deploy decolonizing frames of tension around identity enunciations and other practices, central to their critical vocabulary, and offer an incisive critique of the concept of - identity itself. Additionally, within queer theory, the concept of queer diasporas instructively signals the crisis in identificatory practices for queers of colour. This essay therefore seeks to understand what transformative meanings emerge when queer of colour diasporic literary and artistic practices are made to bear upon the critical notion of decolonial enunciations. With specific reference to the works of the artist Raju Rage (UK) and the fiction of Ocean Vuong (US), it turns to enabling affect of decolonial aesthesis through an engagement with queer and trans of colour frames, diasporas and colonial legacies, and attempts to link theoretical conceptualization to embodiment/inhabitation of queerness.
\end{abstract}




\section{Queerness, decolonial healing, enunciations}

Think about the British Indian girl who wears a sari to class every day. And listen again to Joshua's accent, and hear in it not failure to communicate, but a casual, everyday protest - a way of saying, I don't have to sound like you to be worthy of being heard. (Mignolo and Michelle K. 2013)

Thus, rather than apprehending shock/outrage, resistance, and healing as elements in a dialectical relationship, I hold them as threads that weave diverse works of art intentionally and intuitively into a decolonial aestheSis. (Shilliam 2013)

This essay connects several strands of recent critical theorization of decoloniality and queerness locating them in a cognate bind. It traces the convergences of both fields of critical inquiry and makes the case for multiplying twinpronged decolonial and queer analyses of practices, cultures, literatures, and arts. Extending the analytic of queer diasporas, it gestures towards extending the critical grammar to include what I term "decolonial queer diasporas". As such, it offers renewed conceptual models which incorporate fully queer diasporic experiences. Positioning queer diasporas in the wider frame of decolonial queerness allows a reassessment of queer diasporic critique, whilst simultaneously undermining the coloniality of standard Euro-American accounts of queerness. Emblematic of the thrust of decolonial and queer analyses in conjunction, decolonial queer diasporic critique, as I aver, proliferates instances of multi-focal appraisal of sexual, gender, racial and trans/national discourses. In so doing, it uncovers auto-ethnographic approaches of queer diasporic artists and writers to address the colonial wound and, through access to archival knowledge and articulation of decolonial aesthesis, commence the process of healing.

Pursuing my earlier work on decolonial queerness, I seek to understand what dissenting meanings emerge when queer of colour diasporic literary and artistic practices act upon the critical notion of enunciation. With specific reference to the works of the artist Raju Rage (UK) and the fiction of Ocean Vuong (US), this essay sets out to enable readings of decolonial aesthesis through an engagement with queer and trans of colour frames, diasporas and colonial legacies, and attempts to link theoretical conceptualization to embodiment/inhabitation of queerness. Reading two separate critical fields and two disparate migratory routes (South Asia/UK and Vietnam/US) in a singular examination appears particularly apposite (despite the challenges), since cross-disciplinary and transnational locations afford the capacities to augment the tools of analysis. However, akin to the conceptualization of decolonial option, which is one of the several options available, decolonial queer diasporas, I suggest, are one of the myriad possibilities. In this regard, I concur with the proposition that they function "as one in a range 
of possible modalities that may well open up new ways of looking translocally at space and race" (Bacchetta, El-Tayeb, and Haritaworn 2019, 168).

\section{Queer and decolonial crossings}

1 Whilst queer mobilization in countries of the global South, in general, pivots on debating the decriminalization of homosexuality (e.g. India decriminalized consensual (homo)sexual acts on 6 September 2018) or experiencing/ surviving queer lives under occupation (e.g. Palestine: see Alqaisiya, Hilal, and Maikey 2016; Alqaisiya 2018), the focus on same-sex marriage, homoparenting, adoption and filiation has gained ubiquitous
Coalescing queer studies and decolonial theory in contemporary critical research has produced nuanced epistemes of social, cultural, geopolitical, and economic thinking. Drawing upon queer of colour critique (Muñoz 1999; Manalansan 2003; Ferguson 2004; Gopinath 2005), decolonial feminism and lesbianism (Anzaldúa 1989; Lugones 2010), homonationalism and Native/Indigenous queer studies (Puar 2007; Smith 2010; Driskill et al. 2011), queer migration, ethnicities, and refugee politics (Luibhéid and Cantú 2005; El-Tayeb 2011; Chávez 2013; Lewis and Naples 2014) inter alia, the field of decolonial queerness demonstrates the productive crossings of analytic frames as attested in the collective anthology of the Decolonizing Sexualities Network (DSN) titled Decolonizing Sexualities: Transnational Perspectives, Critical Interventions (Bakshi, Jivraj, and Posocco 2016). Additionally, explicit fettering of queer to coloniality of power instantiates the novel productions of the field (see, for instance, Abou Assab 2017; Tschalaer 2019). The primary concern of such braiding addresses, to put it simply, the normative coloniality of queer studies by enabling a dialogue between queer and decolonial analyses, productively resisting (and healing from) Euro-American-centrism of queerness. ${ }^{1}$ Simultaneously, queer interventions in decolonial studies significantly contribute to the pluriversal formations that have enriched the potential span of decoloniality since its inception. ${ }^{2}$ In other words, as instructed in the introduction to this special issue, the nascent domain of decolonial queerness attaches to, without eschewing equality, narratives of justice, transnational imbalance of power, and ethics of solidarity across cultures and species. The conceptualization of decolonial queerness ventures beyond the realm of conventional accounts of gender sexuality and queerness. $^{3}$

In several ways, both decolonial and queer scholarship aspire to destabilize the relations between the periphery and the centre, the marginal and the dominant, and subvert the boundaries of gender/sex/nation. Cautiously reassessing queer coloniality of power and positioning queer contexts within the larger debates on decoloniality, the work of Lugones, Bacchetta and the DSN collective provides a constant evaluation of queer theoretical boundaries such that newer optics of social justice inquiry can emerge. Therefore, a transdisciplinary alliance appears not only productive but also ought to become, in the contemporary moment, the raison d'être of such theories that aim to achieve a 
traction in queer movements across the global North even though recent theorizations of settler colonialism and queerness, and queer and trans people of color (QTPOC) coalitions have emerged subsequently. 2 The theorization of pluriversality borrowed from the Zapatista uprising and Raimon

Pannikar's notion of

"diatopic

hermeneutics", as Mignolo suggests (2018a, ix), signals the cognizant effect of experiencing two or more cosmologies and not simply systems of knowledge - where diverse worlds coexist. Recent explorations of pluriversality include radical interdependence within ecological systems (see Escobar 2018).

3 See, for instance, the trailblazing collection on black veganism and feminism titled Aphro-ism (2017) by Aph Ko and Syl Ko, especially pp. 50-5, 70-81. For a critical queer Indigenous multispecies relationality beyond the settler colonial frame in North America, see TallBear and Willey (2019), especially the introduction. radical political and social transformation. The political call to enact a decolonial turn in queer studies materialized in the last decade. Explicitly referenced through María Lugones's $(2007,187)$ enactment of "liberartory possibilities as de-colonial possibilities" in accounting for the eurocentred colonial creation and enforcement of gender and heterosexual norms in the colonies, the demand of co-producing queer and decolonial analyses historicized the "deep imbrication of race, gender, class, and sexuality."4 Further, Paola Bacchetta $(2009,2010)$ argued that the co-production and co-formation of decolonial knowledges for the lesbian of colour movement(s) in France, for instance, remain "unintelligible in the dominant grid of intelligibility because the grid cannot account for the inseparability of gender, sexuality, race, racism, class, slavery and postslavery, colonialism and postcoloniality" (2009). Extending decolonial theory through co-produced knowledges around genders and sexualities allows Bacchetta's research to theorize novel perspectives around lesbianism, race, and region. ${ }^{5}$ The ongoing critical reflection on decolonial readings of queerness thus appears necessary since heteronormativity is sustained upon epistemic categories, among others, of race, sex, man and woman.

Whereas today decolonization and decoloniality are invoked in many contexts, the triad modernity-coloniality-decoloniality is especially apposite for delineating the field of decolonial queerness. Decolonial scholars have signaled the emergence of the critical category of decolonial analysis that interrogates systems of dominance and their authority to produce a coloniality of power. The singular force of such coloniality that follows from western colonial encounters regulates the inegalitarian worlds that we inhabit through a mono-epistemic organization around the modern West and the capitalist/heteropatriarchal "cultural Europeanization" to borrow from Aníbal Quijano (2007, 167; for an exhaustive list of similar scholarly analysis, see Wynter 2003). At this intersection, decolonial queerness is necessary not only to resist coloniality but also, above all, to re-exist and reemerge decolonially, as Mignolo would assert. As such, decolonial queerness speaks directly to the larger spectrum of decolonial thinking and doing. Exemplary of such entanglements, the Decolonise UKC Project at the University of Kent, UK (www.decoloniseukc.org) demonstrates one of the recent manifestations of common concerns of both decolonial and queer mobilization. One of the key staff mentors of the project, Dr Suhraiya Jivraj, acts as the co-director of the Centre for Sexuality, Race, and Gender Justice (SeRGJ) and is one of the founding members of the DSN collective. Such intertwining configurations highlight the ineluctable crossings of queer and decolonial concerns and, more importantly, illustrate the shared commitments of both the fields. 
4 The colonial reification of binary

genders and heterosexuality including perceived native American homosexualities consolidated the coloniality of power in the United States and served to create a genealogy of the conventional system of marriage as we know today. See, for instance, Mogul, Ritchie, and Whitlock (2011). In terms of British colonization, the colonial intervention displaced precolonial Persian configuration of genders and sexualities. For a detailed account, see Najmabadi (2005).

5 In her recent examination of queer visual diasporas, Gopinath $(2018,30)$, in a way, extends Bacchetta's formulation of coformation and coproduction to incorporate the notion of the translocal with a view to "link disparate transnational locations" such that "new models of sexual subjectivity ... come into focus." Similar emphasis on the co-constitution of sexual, regional, class, and racial categories informs current scholarship in race and sexuality studies since, as the authors of Race and Sexuality posit,
To overcome the embattled oppositional binary of the colonizer-colonized, often considered the over-arching signifier in much standard scholarship of colonial relations, this essay insists on practices such as writing and creating artworks, as exemplars of decolonial thinking and doing that encapsulate modalities of critiquing power imbalances but, more importantly, signal towards healing through decolonial aesthesis. In sum, this essay hinges on one key question: What alternative possibilities emerge when queer diasporic practices critique coloniality of power? In this respect, the colonial matrix of power, as Walter Mignolo (2018b, 142) suggests, "is a complex structure of management and control composed of domains, levels, and flows." This implies a continuation of coloniality after formal decolonization or independence "within all the domains used to categorize and classify the modern world," including the "aesthetic, ethnic/racial, sexual/gender subjective" (Mignolo 2018b, 142). A further subset of questions includes: What does it mean to decentre Eurocentrism in queer diasporic artistic practices such that an optic of decolonial queer diasporas can emerge? How do queer practices of the diasporas negotiate the colonial wound with a view to reemerge and heal from the colonial wound? These questions thus become a modality of thinking and reorienting purportedly peripheral knowledges in other directions than the almost fossilized binary of the colonizercolonized.

In what follows, I tend to the domain of aesthetics and fiction as queer diasporic enunciations such that the generative possibilities of "changing the terms of the conversation" - enunciation - can emerge and that would further "change the content" of the conversation - the enunciated (Mignolo $2018 \mathrm{~b}, 144)$. As Mignolo (2018b, 144) suggests, "it is at the level of the enunciation that the rhetoric of modernity is ... transformed, legislated, and authorized." Consequently then, akin to Frantz Fanon, Mignolo (2018b, 144) suggests, "decoloniality shall focus on changing the terms of the conversation" and not the reverse of changing the content, which does not accomplish the transformation of knowledge and knowledge systems. ${ }^{6}$ Ploughing through and extending the analytics emerging in the aesthetics of diasporic queer communities, I institute what I call "decolonial queer diasporas" as an optic with the capacity to intuit and instruct the reorientation of the terms of the conversation. Through an engagement with two queer diasporic expressions, i.e. the artworks of the London-based interdisciplinary artist Raju Rage (www.rajurage.com) and the first novel titled On Earth We're Briefly Gorgeous (2019; On Earth subsequently) of the US-Vietnamese diasporic writer Ocean Vuong, I underscore the significance of decolonial aesthesis to segue from the experiential "I" of decolonial practice to the observational "eye" of decolonial regeneration to produce and sustain 
"racialization is always already sexual, and sexualization is always already raced" (Vidal-Ortiz, Robinson, and Khan 2018, 26). allegedly peripheral knowledges. Reemerging through decolonial aesthesis, as I suggest, co-produces and co-reconfigures knowledge systems relationally and critically, and emplaces healing as being integral to the process of acknowledging the colonial wound.

\section{From queer diasporas to decolonial queer diasporas}

6 The broader level of

the creation and control of knowledge, according to Mignolo (2018b, 169), defines enunciation per se. Enunciation, in this respect, "is the level in which actors, languages, knowledge generation, and institutions enable the circumscription of the domains of the enunciated" (see also 2018b, 177-8).
Raju Rage and Ocean Vuong belong to transnational diasporas and their works recall the complex relation of empire, post-empire migration (Rage), war and displacement (Vuong) and queer of colour affiliations. Rage is of South Asian origin and resides in London (UK); Vuong is a Vietnamese refugee who arrived with his family in the United States as a two-year-old child. Vuong's novel, akin to his poems, comprises auto-ethnographic worldmaking reinforced by the first-person narrative. Working in the interstices of memory, queerness, and diasporas, both Rage and Vuong communicate the impact of fractal colonial wounds and possibilities to reemerge decolonially through their poetry (Vuong), performance (Rage), artwork (Rage), and fiction (Vuong). At first glance, Rage affirms a trans diasporic critique with conventionally queer performance works on visibility and other queer issues (http://www.rajurage.com/2017/01/visibility-or-opacity-berlin/). However, an exhaustive analysis of their performance pieces reveals the constitution of a trans-diasporic aesthetic which incorporates the decolonial concept of sensing through language, through clothing and even olfactory sensations. Similarly, Vuong's novel On Earth corresponds to the normative queer trope of a coming-out novel as the auto-ethnographic narratorauthor enacts the disclosure of his sexuality to his mother via the epistolary mode. As Rigoberto Gonzalez (2019) succinctly summarizes,

the book centers around the strained relationship between a mother, who struggles with PTSD induced by memories of the Vietnam War and her abusive marriage, and her son, who is contending with his sexuality as he comes of age on the drug-ravaged streets of Hartford, Connecticut. (https://www.pressreader.com/usa/poets-andwriters/20190701/281522227570906)

Both Rage and Vuong's works reference queer cultural enunciations in the broader context of local, global, diasporic, racial and transnational affiliations of queer subjectivity.

Queer diasporic critique as a reading practice enacts alternative configurations of patrilineal descent, belonging, nation and First/Third world binaries based on temporal, spatial, linguistic and other such identificatory markers (Manalansan 2003; Gopinath 2005). Further, a queer diasporic lens reveals 
transnational similarities and discontinuities of queer practices. A turn to queer diasporic reading practices therefore opens spaces for comparative analysis that expand geographical boundaries to "other" disparate geopolitical sites. As Gopinath $(2018,6)$ affirms, the aesthetic, to which I would like to add literary practices, of queer diaspora "negotiate diasporic movement in multiple geographical locations, and suggest other ways of being in and moving through these spaces that deviate from ... hetero- and homonormative scripts." Utilizing the (decolonial) conceptualization of "sensing and knowing" without explicitly referencing decolonial studies (Mignolo and Vazquez 2013), Gopinath $(2018,8)$ adds that this queer mode of critique "demands a retraining of our vision and a reattunement of our senses, and in so doing points to the limits of the entire apparatus of vision that is the inheritance of colonial modernity." In their work on decolonial aesthesis, Walter Mignolo and Rolando Vazquez propound a contiguous facet of knowledge systems that devalue non-Eurocentred formations in the fields of art and beauty. Offering an assessment of western epistemological constructs, they argue for a decolonial process of "sensing, knowing, and believing" that comprises

perception, limen - the smallest sensation, masking, visual sensation/vision odour/ olfactory perception, gustatory or taste sensation, auditory sensation/sound, and synaesthesia - a sensation that normally occurs in one sense modality occurs when another modality is stimulated. (Mignolo and Vazquez 2013)

Arguing for a non-Eurocentric mode of knowledge production, decolonial thinking goes further than the purportedly objective observational/analytical eye to incorporate instances of knowledge production that are in the realm of sensing through feelings/emotions/affects or even subjective knowledge that becomes the archive, which is akin to Gopinath's $(2018,11)$ formulation of "archival practices that excavate and memorialize the minor histories (personal, familial, collective, regional) that stand outside of official nationcentred narratives." Decolonial thought becomes one mode of thinking/of knowledge production - often labeled as the decolonial option - among many others, thus establishing the primacy of pluriversality over universality. Decoloniality is not a command to think in a specific mode, nor is it the ungraspable, the ever-evanescent limen, but an option.

Decolonial queer diasporas as an emergent co-constitutive term, co-produced by histories of migration, generational transnational knowledges and queerness, functions as a modality of reading and, in this regard, operates as an option. It mobilizes the personal, the familial, the collective and the regional, to borrow from Gopinath, and goes beyond the institution of archival knowledge to enact a decolonial emancipation of queer diasporic critique. Pointing to other sensorial affiliations of knowledges (memory, touch, 
sensation, feeling), it professes an option of sensing knowledge that come into focus but remain excluded from predominantly circumscribed accounts of perception and observation in standard epistemology. Decolonial queer diasporic practices operate, to borrow from decolonial scholars, "from the margins and beyond the margins of the modern/colonial order" (Mignolo and Vazquez 2013). The experience of multiple exclusions generates, as Bacchetta, El-Tayeb, and Haritaworn contend $(2019,164)$, "translocal alliances" and "locally grounded spacemaking" through "claiming hostile or indifferent spaces or through excavating a local genealogy of QPoC activism that continues to be excluded from the archives."

Rage and Vuong's works recall the modern/colonial order by explicitly emplacing themselves within diasporic locations. However, the enactment of the critique of coloniality goes beyond the margins of the colonial order to incorporate knowledge regimes that lie outside conventional realms of knowledge-making or even queerness. Decolonial queer diasporas as an optic does not simply enact critiques of either queerness or nation/affiliation and canonical knowledge systems. Instead, what comes into focus is a comprehensive terrain of practices that create an option for the artiste, the writer, the performer and by extension for the public, the audience, the reader. The knowledge that (re)emerges is both personal and collective but, more significantly, is not simply "knowing" but "sensing". Such knowledge (s) reside(s), as Rage's biography on their website attests, in "utilizing everyday life experiences in communicating narratives around gender, race and culture" (http://www.rajurage.com/who-i-am/).

Interrupting routine narratives of diasporas (belonging/nation/cultural affiliation/myth of return to homeland) and even queerness (homophobia in biological families/the appeal of metropolitan cities), decolonial queer diasporas sustain the personal, familial and the public-private binary in a consistently molecular relationality with all the problematic complexities it entails. Rage uses their "non-conforming body as a vehicle of embodied knowledge to bridge the gap between dis/connected bodies, theory and practice, text and the body and aesthetics and the political substance" (http:// www.rajurage.com/who-i-am/). Additionally, Rage's work continuously indexes their own body as a co-producer of knowledge instituted through multiple migrations (UK-East Africa-South Asia) and references histories of other bodies through sartorial practices (turban/sari: http://www.rajurage. com/2015/11/asian-futures/), and food and spices outlining the BritishSouth Asian continuum in their performance titled "Project/ed" (2014) (http://www.rajurage.com/2014/10/projected/). Rage's body becomes the vexed site of routes of trade, and of colonial knowledges of economies even as it records and archives this coloniality. The performance emblematizes, as Rage suggests, "a haptic moving image narrative consisting of projected 


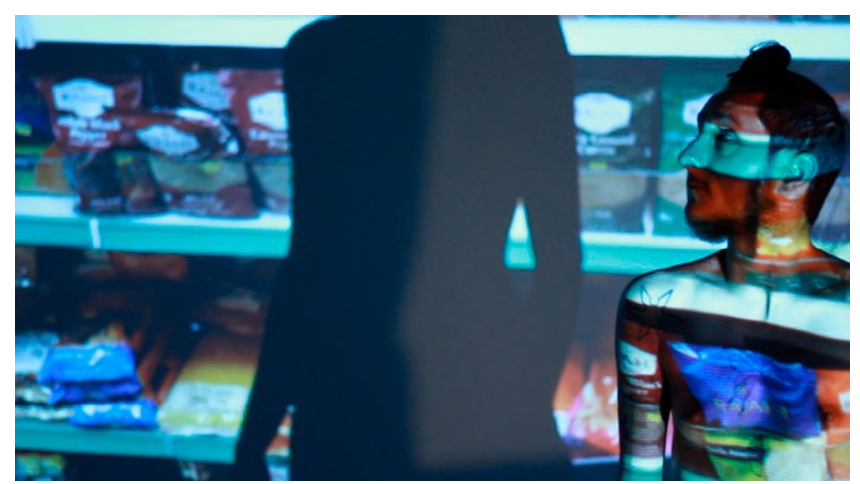

Figure 1 (c) Raju Rage. Reprinted with permission from the artist.

archival images depicting South Asian migration onto a gendered non-conforming body" (http://www.rajurage.com/2014/10/projected/) (Figure 1).

Throughout the video narrative, Rage astutely accesses the archive of migration through foregrounding the projections of othered bodies of South Asians onto their own non-conforming body. Foregrounding the non-normativity of their body, in a way, queers the archive of migration. However, the spectre of colonization and forced migration achieves visual clarity in the complex interaction between the spice packets of brand "Rajah" ("King" in Hindi and Punjabi) and depiction of colonial erasure from the standard archive in the closing shots. In a series of successive snapshots, the narrative rushes headlong into colonization and its impact on memory. The images of Sikh soldiers - Rage has in part Sikh heritage - projected onto Rage's body actualize South Asian conscription in the two world wars, which has often been occluded in conventional narratives of valour and heroism. Central to the vignette of colonial oversight, Rage's queer and trans-diasporic subjectivity positions itself as the repository of knowledge; of knowing, and believing, the stories of their ancestors. Rage's body senses, almost in a haptic moment, the intergenerational affect of Sikh subjectivity. This instance altogether partakes in the articulation of the trans-diasporic subjectivity that through memory reemerges decolonially.

A striking consonance with Rage's concerns appears in Vuong's relation to his own body in the poem "Ode to Masturbation" (2016), whereby the private act of masturbation is subsumed under the spectacle of public verbalization. Analysing the play between private and public interaction in relation to the poet's body and those he desires, Summer Kim Lee (2019) explicates that "a mode of relating emerges ... through the slippage between 'other bodies' that are not his own and the 'we' of Other minoritarian bodies, including his own as a queer Vietnamese American refugee." Decolonial queer diasporas, in this frame, partake in the construction/generation of archival 
7 The word

"monument" and its attributes

"monumental" and

"monumentalize"

when used in

literature reveal the

inclination to make

visible abstract

coloniality (literature)

by ascribing it to

another discipline,

that of architecture.

Thus a "work of

monumental art"

functions as a

perceptible reminder

of the power of

coloniality in a

colonial/neocolonial

context.

8 In literary studies,

for instance, reading

Shakespeare or

Dickens in India,

whereas Macaulay

derided all Indian

literatures when

compared to English

literature, remains a

fraught exercise.

Voltaire's presence in

the French literary

canon in West Africa

likewise should call

into question the

author's views on

black people in

general. The non-

visible markers of

coloniality become

visible only when we

engage racial

formations in

purportedly benign

exercises as

interpretation of

literature. Decolonial

thinkers emphasize knowledge of non-national genealogies that rely on bodies, desires and their queerness as much as on migratory routes, empires, and colonialities. Commemorative colonial monuments and plaques uphold coloniality in the formally postcolonized global South and, as Achille Mbembe $(2017,188)$ remarks, function "as the sculptural extensions of a form of racial terror" to mark the power of the colonial potentate even in the contemporary era. ${ }^{7}$ Movements across the global South such as Rhodes Must Fall exemplify the presence of such sculptural extensions. The visible extensions along with the often non-visible, abstract markers of coloniality such as language, literary canons, and artistic productions, to name a few, render the knowledges of non-European cultures of secondary value. ${ }^{8}$ Therefore, by invoking specific archival knowledge attached to mutual histories and futures through queer and trans-diasporic artists, decolonial queer diasporic practices verbalize/visibilize memory and reemerge from colonial history, as I suggest elsewhere, "through imaginative configuration of memory, language and body" (https://www.decolonizingsexualities.com/2018/05/14/the-decolonialqueer-artist-is-present-and-refuses-to-forget/).

On Earth subtly interweaves his/her-stories of Vuong (called "Little Dog" in the novel), his mother, and his grandmother. Even though it borrows from the genre of coming-out narratives, the divulgence of queerness in a letter drafted by Vuong to his mother who cannot read English accompanies the narrative of national histories, war in Vietnam, rape by American soldiers (23), his mother and grandmother's intergenerational trauma, migration, his mother's abusive comportment, and Vuong's own bullying at school for both being a foreigner and an effeminate boy in the United States (24-5). As Vuong the narrator-author realizes in his cogitations on the past, the novel itself becomes "The History of Memory" (8). Memory makes intelligible not just the ubiquitous presence of war in the lives of three generations, as he questions "When does a war end?" (12), but in a simultaneous movement it mobilizes the regeneration of intergenerational alliance, since memory is "a flood" and not "a choice" (78). Reflecting on his own act of writing, Vuong fuses his body with that of his family towards the end of the novel: "I never wanted to build a 'body of work,' but to preserve these, our bodies, breathing and unaccounted for, inside the work (175)." The act of preservation, like for Rage, documents the archive of lived experience intergenerationally. ${ }^{9}$ The literary aesthetic in this regard instantiates the personal stories as archival artefacts valued for their generative possibilities. Further, in her elucidation of brown queerness, Sara Ahmed $(2017,52)$ decries the explicit attribution of homophobia to brown families whereby the brown family "is imagined as a dead weight" and "there is an expectation that her family will be more oppressive, less tolerant, less supportive" of the queer child. Certainly then, Vuong's fashioning of the familial bond, given the background of the disclosure of his queer sexuality, points to the inveterate complexity of diasporic queerness. 
such bi-focal

readings. Also, see the

refusal of a

Martinican-French

student to attempt the

question on Victor
The connected intergenerational bond circumvents neat relegation of homophobic attachment to migrant families.

\section{Towards decolonial aesthesis and healing}

Hugo in the 2019 baccalaureate exam (https://www. youtube.com/watch? $\mathrm{v}=$ afPsKU0Qlto).

9 Incidentally, both Vuong and Rage explicitly reference the work of Puar and Rai (2002) on racialized and sexualized exclusions through pathologization of their own bodies in "monster-terroristfag" characterization. See Vuong (2019, 13-14) and Rage's 2014 performance in Berlin titled "The Dilemma of the Diaspora to Define featuring Monster, Terrorist, Fag" (https://www.vimeo. com/106290102).
Queer diasporas and decolonial queer diasporas create meaning and value through their visible attachment to elements purportedly considered of inferior worth in standard narratives of art, aesthetics, literature and cultural practices. Despite exclusionary practices of dominant discourses, Rage's use of South Asian dress, spices, and language, and Vuong's extended description of his mother's extractive labour in a nail salon in the United States (78-94) or his grandmother's favourite dish of tea-rice, secure such elements as intrinsically valuable. In articulating the migratory experience, queer diasporic subjectivity acknowledges the colonial wound and highlights the importance to resist it through providing valence to quotidian objects (Rage) and acts (Vuong). For instance, pondering on the migrant labour economy of the nail salon and its repercussions on his mother's body, Vuong finds love in the abomination of her scaled hands. $\mathrm{He}$ expresses the value of her labour through an attachment to her damaged hands: "I hate and love your battered hands for what they can never be" (81). The utterance reveals the emotional labour of queer diasporic communities to esteem underpaid migrant work and resulting bodily impairment.

Even though queer diasporas and decolonial queer diasporas as analytics underscore the significance of valuing that which is routinely excluded or "reading the dominant archive through the minor" (Gopinath $2018,16)$, the latter gestures towards healing from the colonial wound as inherent to the diasporic experience. In this regard, decolonial queer diasporas as an optic extends the possibilities of reading practices. The theorization of decolonial aesthesis and its application to queer diasporic critique, in my view, aptly conjoins transformative empowering politics (doing and sensing) encapsulated by decolonial healing to making visible the colonial wound (knowing). As Mignolo and Vazquez (2013) state, "Decolonial aestheSis departs from an embodied consciousness of the colonial wound and moves toward healing." It is precisely in and through this movement (of healing) that decolonial queer diasporic artists, writers, performers, and poets create aesthetic departures from the Eurocentric canon.

In his essay titled, "Be.Bop 2012. Black Europe Body Politics," Robbie Shilliam (2013) provides an insightful discussion of decolonial aesthesis of the Be.Bop artistic installations, through a genealogy of literary examples of 
Edouard Glissant, Aimé Césaire, and Chinua Achebe. For Shilliam (2013), "decolonial aestheSis resides less with Derrida or Foucault and dwells much more in Glissant and Achebe." He adds that, "often relegated to 'romanticism' by (post-)moderns who patrol the boundaries of high art and social science, these decolonial aestheSis nevertheless hold the potential to recultivate the world in a new dispensation." Finally, he delineates the definition in three points and remarks on the absence of the third strand in postcolonial studies. He states that decolonial aesthesis is: "(1) the shock and outrage of realizing a colonial wound, (2) collective resistance to the harmer, and (3) collective self-healing. Postcolonial studies have been very useful for attending to the first two." This working definition of decolonial aesthesis is particularly apposite to analyse the work of queer diasporic writers and artists.

Healing, as Bacchetta, El-Tayeb, and Haritaworn $(2019,164)$ suggest, is "sustained through translocal alliances." The access to archival intergenerational knowledge through the bodies of Rage and Vuong, as mentioned above, becomes a method of work in not only acknowledging and resisting the colonial wound, but also in opening the decolonial wound to forms of collective healing, as suggested by Shilliam. In an interview with Rubén Gaztambide-Fernández, Mignolo centres the notion of collective healing as an imperative of decolonial aesthesis. He notes:

Through knowing, understanding, decolonial artistic creativity and decolonial philosophical aestheSis, and above all by building the communal (not the Marxist commune, nor the liberal common good, but the communal; the legacies of "communities" beyond Eurocentric legacies of Christian and secular family and "society". (Gaztambide-Fernández 2014, 207)

Thus, personal healing, for both Rage and Vuong, embodies collective selfhealing through the evocation of ancestors for Rage and alliance with his Vietnamese mother and grandmother for Vuong.

A realization of the wound can only ever be the first step in a long-drawn process that requires completion in the form of healing. The depredations that Vuong endures through the humiliation of being effeminate, of being queer in relation to his mother, of learning to speak English as a refugee, having constantly to translate into Vietnamese for his mother, and of losing his first love Trevor to drug overdose, attune him to multiplylayered wounds that are both personal and collective. However, an acknowledgement of the wound, as he is aware, does not imply closure. As he describes:

I was once foolish enough to believe knowledge would clarify, but some things are so gauzed behind layers of syntax and semantics, behind days and hours, names 
forgotten, salvaged and shed, that simply knowing the wound exists does nothing to reveal it. (Vuong 2019, 62)

Since the knowledge of the wound can, in some ways, revive the wound since "the past (is) never a fixed and dormant landscape but one that is reseen" (28), Vuong asserts the primacy of healing from the wound, from the past, and from memory itself even though it implies not forgetting but paradoxically remembering the wounds. The narrative reinforces this notion of reminder through reprising strategic incidents of negative affect. As Vuong $(2019$, 85) writes to his mother, "through this careful bruising, you heal." In the third section of the novel, Vuong enacts the process of healing necessary for creativity as he responds to the question his mother had asked earlier about what makes a writer. He upends conventional knowledge on creation as healing by placing healing prior to the act of creating. Tethering healing to the aesthetic consciousness, this section instantiates the co-production of decolonial aesthesis through an acknowledgment of the colonial wound and commencement of the process of healing. Challenging the premise of the Eurocentric canon and its association with death and language of destruction, Vuong $(2019,179)$, through his interrogations, alludes to life-sustaining art: "But why can't the language for creativity be the language of regeneration?" Like Rage's enunciation of the haptic images that traverse the body of the artist to affirm lives of dead Sikh ancestors, Vuong critiques the canon and goes beyond critique to espouse a fuller comprehension of life. As he says, "the truth is we don't have to die if we don't feel like it" (Vuong 2019, 180). The twin consciousness of death and life in a single sentence points to the hope that attaches to feelings of sadness. As Mignolo and Vazquez (2013) suggest, the aim of decolonial aesthesis is "not to produce feelings of beauty or sublimity, but ones of sadness, indignation, repentance, hope, and determination to change things in the future." The regenerative aesthesis supports, for Vuong, the potential of healing and life, which will enable him to reemerge decolonially, thus freeing himself from his own coloniality and colonial subjectivity.

In a similar vein, healing, for Raju, surfaces in the enactment of aesthesis that "cultivates knowledge that is other-wise to (if unavoidably entangled with) the modern subject - i.e. the subject of violence" (Shilliam 2013). This violence is perpetrated through the "normative framework" of western aesthetics and its self-referential exclusionary tactics (Mignolo and Vazquez 2013). In their performative installation titled "There is More at Stake than 5 Metres of Cloth," Rage (2015; http://www.rajurage.com/2015/11/asianfutures/) foregrounds the significance of non-western clothes and their histories embedded in textile cultures of South Asia, and fabrics that have 


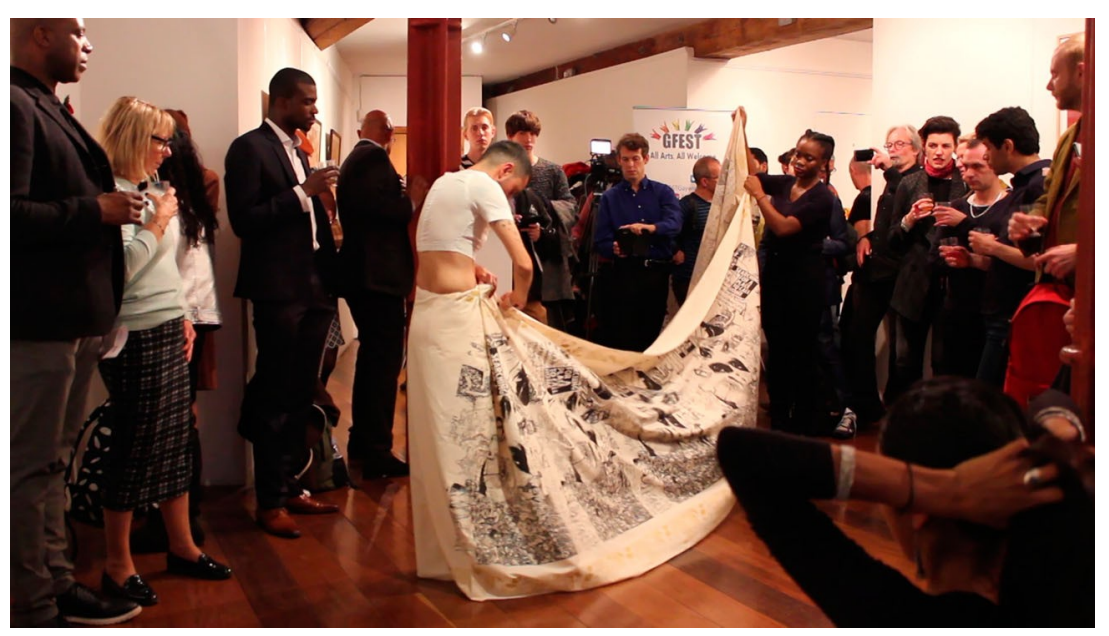

Figure 2 (C) Raju Rage. Reprinted with permission from the artist.

10 The site of the museum is a fraught one for diasporic people and

communities of the global South. As early as 2002, Russell Thornton argued for the repatriation of colonial artefacts as integral to the healing of communities (20). In recent times, the French President instituted a committee under the aegis of Felwine Sarr and Bénédicte Savoy to undertake repatriation of museum objects to Western Africa (see the report at http:// www.restitu tionreport2018. com/sarr savoy_en.pdf). traveled both in time (as in generational time) and in geographies. The process of healing through decolonial aesthesis begins when Rage walks around the gallery tying the turban and the sari in front of an audience of museum curators (Figure 2). ${ }^{10}$

Rage's sensing of the world and creation of the sensory knowledge archive is exemplary of decolonial aesthesis, which is "an unelaborated elementary awareness of stimulation; 'a sensation of touch"' (Mignolo and Vazquez 2013). The healing from this performance resides in the act of queerly touching the cloth (of two separate genders - the turban and sari) as it compellingly contains the knowledge of migrant labour, histories of displacement, and dress that is peripheral to both the nation (in this case, the UK) and the space (Menier Gallery, London).

Excavating archival knowledge and genealogical epistemologies occurs as one of the key characteristics of decolonial aesthesis that engenders healing. Geopolitical power imbalances, however, conceal such knowledges residing in intergenerational continuities. Vuong, for instance, consciously accepts the failure of the Vietnamese language to afford him this possibility, since his ability in the language reaches "only the second-grade level" (Vuong 2019, 31). The sole way to access the past in this arrangement for him is the language of touch and it is the reason why he massages his mother to demonstrate the care and alleviate the pain of her work-intensive day at the nail salon. Nevertheless, in the third section of On Earth, in a series of carefully crafted sentences, Vuong signals a healing process through a comparison of English and Vietnamese. For instance, he writes: 


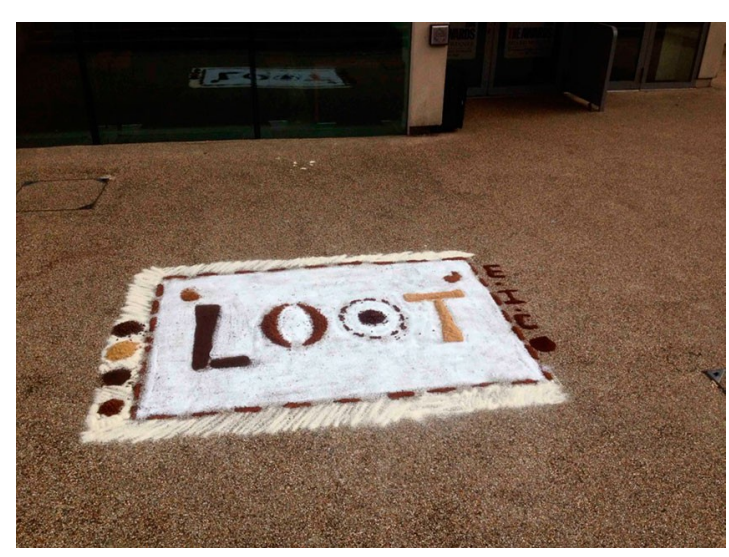

Figure 3 (C) Raju Rage. Reprinted with permission from the artist.

In Vietnamese, the word for missing someone and remembering them is the same: nho. Sometimes, when you ask me over the phone, Con nho me không? I flinch, thinking you meant, Do you remember me?

I miss you more than I remember you. (Vuong 2019, 186)

Comprehending the difference in language systems despite his lacunas becomes for Vuong a healing process of accessing archival knowledges of the ancestors. His reflection in this section on the act of writing itself is informed through these knowledges that are produced through sensations produced by touching: "Is that what art is? To be touched ..." (Vuong 2019, 189).

For Rage, othered knowledges reside in the borrowed words from South Asian languages that materialize in the English language. In their text installation in Cambridge, UK, titled "Loot" (2015), Rage reflects on "one of the very first Indian words to enter the English language ... the Hindustani slang for plunder: 'loot"' (http://www.rajurage.com/2015/10/744/). The installation comprises the etching of the word "loot" on the grounds of Anglia Ruskin University, Cambridge, by using colonially traded products, such as tea, coffee, tobacco, and sugar (Figure 3).

Whilst the colonial commodification functions to remember the extractive trade of the East India Company appearing as EICO to the right, it is the forgetting of the loan from Indian languages that becomes crucial in the installation. To borrow from Hypatia Vourloumis's metaphor of the "haptics of language," this contact between the two languages brings into focus the touching (both sensual and non-consensual) between two knowledge systems $(2014,235)$.

As I suggest elsewhere (https://www.decolonizingsexualities.com/2018/05/ 14/the-decolonial-queer-artist-is-present-and-refuses-to-forget/), within South Asian communities the decorative art form of Rangoli - patterns of coloured rice, sand, flour, flower petals or leaves on the floors or courtyards 
- connects to cultural beliefs of prosperity, good luck and overall well-being. Rangolis appear during festivals, weddings and other auspicious occasions when women sketch traditional aesthetic designs, which become markers of inter(re)generational memory. Connecting to the cultural practice of Rangoli, Rage's text installation enacts the memory of colonialism through recourse to the artistic legacy of their people(s). Even though this critical intervention and engagement with cultural heritage enables Rage to perform the act of not-forgetting the exploitative colonial trade, it wrenches the colonial wound from the domain of trade and commerce and places it securely in the field of intergenerational continuum of creativity such that the process of healing commences.

\section{Conclusion}

Throughout this essay, I have endeavored to implicate decolonial diasporic enunciations in queer formations that document, challenge, and inscribe their her/his/stories in standardized and canonical archives, artmaking practices, and literary productions. Queer and trans-diasporic decoloniality mobilizes aesthetic and archival practices which, relegated to the minority status and peripheries appear, alongside past and current colonial epistemology, as crucial repositories of knowledge(s). The artistic expressions not only critique the universal appellation of knowledge and its attachment to Euro-American spaces, but also enact the vital task of both personal and collective healing. In so doing, they participate in the theorization of pluriversality and pluriversal knowledges without renaturalizing embedded hierarchies of domination. As a reminder, the genealogies that decolonial queer diasporic practices disclose do not stand in contrast to or perform a hiatus from the authoritative epistemological genealogy. Instead, they spawn other templates, and different trajectories, such that they operate as co-producers of knowledges with the standard epistemological frames. The co-constitutedness of decolonial queer diasporas and Eurocentred accounts of nation, racial exclusions, and coloniality of power in all domains precisely stages the backdrop through which other knowledges can come into existence. Rage, Vuong and several other queer diasporic artmakers, and literary and poetic creators, inevitably understand their implication in authoritative versions of knowledge production. Their engagement with the latter enhances the quality of their enunciation as they coincide, collide, and benefit mutually.

Queer and trans-diasporic artists and practitioners go beyond a facile critique of coloniality to which they are subjected in quotidian experiences. Perceived as racial outsiders in the global North and as gender/sexual nonnormative beings, their critiques of hostile spaces and discrimination, 
however, does not invalidate their regenerative capacities of healing through and with communities of colour, and chosen or biological families. In this regard, decolonial queer diasporas lie outside the purview of national affiliation and exceed the confines of cultural belonging. Transnational similitudes, therefore, as I have indicated in the analyses of Rage and Vuong, characterize the key features of decolonial queerness(es).

This essay contributes to the ongoing appraisal of queer and decolonial crossings that the DSN collective committed to in the last decade. The aesthetic trajectories of Rage and Vuong signal the ways in which decoloniality informs queer studies through radical forms of existence, which aim to destabilize entrenched hierarchies of our times. Healing from the colonial wound through co-creation of archives, through co-production of knowledges, and through co-constitution of critical genealogies, offers (re)generative possibilities that Rage and Vuong allude to in their work. Taking cognizance of the immensity of such politics is perhaps one of the main instructions of decolonial diasporic critique. A decolonial perspective interlinked to queerness should, in my view, inform our own orientations such that the beginning of a transformative process can materialize. The prolific site of decolonial queer diasporas is already pointing toward fabrication of such futures. Remaining alert to these collective narratives of healing, opposition to coloniality of power, and development of emergent queer and decolonial theorization holds momentous potential to accomplish such politics of transformation.

\section{Acknowledgements}

I consider it an enormous honour to know and learn from Raju Rage. Their creative energies and activism ethics propelled the discussions around their work. I am highly obliged to my research centre at the Université de Paris, LARCA (UMR-CNRS 8225) for the generous allocation of travel funds to meet the DSN collective in Kent, where I wrote this essay in part.

\section{Funding}

This work was supported by LARCA, CNRS.

\section{ORCID}

Sandeep Bakshi $\odot$ http://orcid.org/0000-0002-4095-0209 


\section{References}

Abou Assab, Nour. 2017. "Queering Narratives and Narrating Queer: Colonial Queer Subjects in the Arab World." In Queer in Translation, edited by B. J. Epstein and Robert Gillett, 37-48. New York: Routledge.

Ahmed, Sara. 2017. Living a Feminist Life. Durham, NC: Duke University Press.

Alqaisiya, Walaa. 2018. "Decolonial Queering: The Politics of Being Queer in Palestine." Journal of Palestine Studies 47: 29-44.

Alqaisiya, Walaa, Ghaith Hilal, and Haneen Maikey. 2016. "Dismantling the Image of the Palestinian Homosexual: Exploring the Role of AlQaws." In Decolonizing Sexualities: Transnational Perspectives, Critical Interventions, edited by Sandeep Bakshi, Suhraiya Jivraj, and Silvia Posocco, 125140. Oxford: Counterpress.

Anzaldúa, Gloria. 1989. Borderlands/La Frontera: The

New Mestiza. San Francisco, CA: Aunt Lute Books.

Bacchetta, Paola. 2009. "Co-formations: On Decolonial Spatialities of Resistance by Lesbians 'of Color' in France." Genre, Sexualité \& Société 1, doi:10. 4000 /gss.810.

Bacchetta, Paola. 2010. "Decolonial Praxis: Enabling Intranational and Queer Coalition Building." Qui Parle 18 (2): 147-192. doi:10.5250/quiparle.18.2. 147.

Bacchetta, Paola, Fatima El-Tayeb, and Jin Haritaworn. 2019. "Queers of Color and (De)Colonial Spaces in Europe." In Global Raciality: Empire, PostColoniality, DeColoniality, edited by Paola Bacchetta, Sunaina Maira, and Howard Winant, 158-170. New York: Routledge.

Bakshi, Sandeep, Suhraiya Jivraj, and Silvia Posocco, eds. 2016. Decolonizing Sexualities: Transnational Perspectives, Critical Interventions. Oxford: Counterpress.

Chávez, Karma. 2013. Queer Migration Politics: Activist Rhetoric and Coalitional Possibilities. Urbana: University of Illinois Press.

Driskill, Qwo-Li, Chris Finley, Brian Gilley, and Scott Morgensen, eds. 2011. Queer Indigenous Studies: Critical Interventions in Theory, Politics, and Literature. Tucson: University of Arizona Press.

El-Tayeb, Fatima. 2011. European Others: Queering Ethnicity in Postnational Europe. Minneapolis: University of Minnesota Press.

Escobar, Arturo. 2018. Designs for the Pluriverse: Radical Interdependence, Autonomy, and the Making of Worlds. Durham, NC: Duke University Press.

Ferguson, Roderick. 2004. Aberrations in Black: Toward a Queer of Color Critique. Minneapolis: University of Minnesota Press.
Gaztambide-Fernández, Rubén. 2014. “Decolonial Options and Artistic/AestheSic Entanglements: An Interview with Walter Mignolo." Decolonization: Indigeneity, Education and Society 3 (1): 196-212. Gonzalez, Rigoberto. 2019. "Be Bold." Press Reader, July 1. https://www.pressreader.com/usa/poets-andwriters/20190701/281522227570906.

Gopinath, Gayatri. 2005. Impossible Desires: Queer Diasporas and South Asian Public Cultures. Durham, NC: Duke University Press.

Gopinath, Gayatri. 2018. Unruly Visions: The Aesthetic Practices of Queer Diaspora. Durham, NC: Duke University Press.

Ko, Aph, and Syl Ko. 2017. Aphro-ism: Essays on Pop Culture, Feminism, and Black Veganism From Two Sisters. New York: Lantern Books.

Lee, Summer Kim. 2019. "Staying In: Mitski, Ocean Vuong, and Asian American Asociality." Social Text 37 (1 (138)): 27-50.

Lewis, Rachel, and Nancy Naples, eds. 2014. "Queer Migration, Asylum, and Displacement." Sexualities 17 (8): 911-918.

Lugones, María. 2007. "Heterosexualism and the Colonial/Modern Gender System." Hypatia 22 (1): 186209.

Lugones, María. 2010. "Toward a Decolonial Feminism." Hypatia 25 (4): 742-759.

Luibhéid, Eithne, and Lionel Cantú, eds. 2005. Queer Migrations: Sexuality, U.S. Citizenship, and Border Crossings. Minneapolis: University of Minnesota Press.

Manalansan, Martin. 2003. Global Divas: Filipino Gay Men in the Diaspora. Durham, NC: Duke University Press.

Mbembe, Achille. 2017. Critique of Black Reason. Translated by Laurent Dubois. Durham, NC: Duke University Press.

Mignolo, Walter. 2018a. "Foreword: On Pluriversality and Multipolarity." In Constructing the Pluriverse:

The Geopolitics of Knowledge, edited by Bernd Reiter, ix-xvi. Durham, NC: Duke University Press. Mignolo, Walter. 2018b. "The Decolonial Option." In

On Decoloniality: Concepts, Analytics, Praxis, edited by Walter Mignolo and Catherine Walsh, 105-226. Durham, NC: Duke University Press.

Mignolo, Walter, and Michelle K. 2013. "Decolonial Aesthesis: From Singapore, to Cambridge, to Duke University." Social Text Online, July 15. https:// www.socialtextjournal.org/periscope_article/ decolonial-aesthesis-from-singapore-to-cambridgeto-duke-university/.

Mignolo, Walter, and Roland Vazquez. 2013. "Decolonial AestheSis: Colonial Wounds/Decolonial 
Healings." Social Text Online, July 15. https://www. socialtextjournal.org/periscope_article/decolonialaesthesis-colonial-woundsdecolonial-healings/.

Mogul, Joey, Andrea Ritchie, and Kay Whitlock. 2011. "Setting the Historical Stage: Colonial Legacies." In Queer (In)Justice: The Criminalization of the LGBT People in the United States, edited by Joey Mogul, Andrea Ritchie, and Kay Whitlock, 1-19. Boston, MA: Beacon Press.

Muñoz, José. 1999. Disidentifications: Queers of Color and the Performance of Politics. Minneapolis: University of Minnesota Press.

Najmabadi, Afsaneh. 2005. Women with Mustaches and Men without Beards: Gender and Sexual Anxieties of Iranian Modernity. Berkeley: University of California Press.

Puar, Jasbir. 2007. Terrorist Assemblages: Homonationalism in Queer Times. Durham, NC: Duke University Press.

Puar, Jasbir, and Amit S. Rai. 2002. "Monster, Terrorist, Fag: The War on Terrorism and the Production of Docile Patriots." Social Text 20 (3 (72)): 117-148. doi:10.1215/01642472-20-3_72117.

Quijano, Aníbal. 2007. "Coloniality and Modernity/ Rationality." Cultural Studies 21 (2-3): 168-178.

Shilliam, Robbie. 2013. "Be.Bop 2012. Black Europe Body Politics. Decolonial Aesthesis." Social Text Online, July 15. https://www.socialtextjournal.org/ periscope_article/be-bop-2012-black-europe-bodypolitics/.

Smith, Andrea. 2010. "Queer Theory and Native Studies: The Heteronormativity of Settler
Colonialism." GLQ: A Journal of Lesbian and Gay Studies 16 (1/2): 41-68.

TallBear, Kim, and Angela Willey, eds. 2019. "Critical Relationality: Indigenous and Queer Belonging Beyond Settler Sex and Nature." Imaginations 10: 1. doi:10.17742/IMAGE.CR.10.1.

Thornton, Russell. 2002. "Repatriation as Healing the Wounds of the Trauma of History: Cases of Native Americans in the United States of America." In The Dead and Their Possessions: Repatriation in Principle, Policy and Practice, edited by Cressida Fforde, Jane Hubert, and Paul Turnbull, 17-24. London: Routledge.

Tschalaer, Mengia. 2019. "Between Queer Liberalisms and Muslim Masculinities: LGBTQI+ Muslim Asylum Assessment in Germany." Ethnic and Racial Studies, doi:10.1080/01419870.2019.1640378.

Vidal-Ortiz, Salvador, Brandon A. Robinson, and Cristina Khan. 2018. Race and Sexuality. Cambridge: Polity Press.

Vourloumis, Hypatia. 2014. "Ten Theses on Touch, or, Writing Touch." Women and Performance: A Journal of Feminist Theory 24 (2/3): 232-238.

Vuong, Ocean. 2016. "Ode to Masturbation." In Night Sky with Exit Wounds, edited by Ocean Vuong,6167. Port Townsend: Copper Canyon.

Vuong, Ocean. 2019. On Earth We're Briefly Gorgeous. New York: Penguin.

Wynter, Sylvia. 2003. "Unsettling the Coloniality of Being/Power/Truth/Freedom: Towards the Human, After Man, Its Overrepresentation - An Argument." CR: The New Centennial Review 3 (3): 257-337. 